\title{
Feminist Knowledges as Interventions in Physical Cultures
}

\section{Co-editors:}

Simone Fullagar, University of Bath, UK and Griffith University, Australia (contact author)

s.p.fullagar@bath.ac.uk Twitter@simonefullagar

Emma Rich, University of Bath, UK, E.Rich@batha.c.uk Twitter@DrEmmaRich

Adele Pavlidis, Griffith University, Australia, a.pavlidis@griffith.edu.au Twitter@adele_pavlidis

Cathy van Ingen, Brock University, Canada cathy.vaningen@brocku.ca Twitter@cathvi

Recognising the considerable contribution of feminist theories and methodologies to understanding the power relations implicated in embodied movement and knowledge, this collection explores the possibilities of feminist interventions in physical cultures. Contributing authors draw upon a range of disciplinary perspectives, methodological and theoretical approaches that pursue questions about the gendered formation of physical cultures (across leisure, sport, the arts, tourism, well-being and related embodied practices). Several authors also offer a feminist engagement with emergent interdisciplinary field of Physical Cultural Studies (PCS) to consider the knowledge practices that shape debate about gendered bodies, relations and social change. The thread that connects these diverse approaches is the 'doing' of feminism as generative knowledge practice through particular theoretical and methodological trajectories that situate physical culture in particular material, discursive and affective relations (Braidotti, 2013). Feminist interventions in physical culture involve, in Sara Ahmed's (2017, p. 13) words, an enactment of "sweaty concepts" which refers to the explicit acknowledgement of how research and writing are always mediated by theoretical assumptions that 'do' things in the world.

Thinking and writing through sweaty concepts enables feminists to play with and mobilise embodied, affective orientations that can disrupt normative ideas, identities and ways of knowing.

The collection explores wide ranging topics and debates, such as, the embodiment of netball through feminist Physical Cultural Studies; pregnant embodiment and implications of the postgenomic turn; posthumanist perspectives on women's negotiation of affective embodiment and an autoethnographic account of how masculinity materialises through football; the mediation of gendered subjectivity through the digital-physical cultures of cycling; and how decolonial and postcolonial approaches identify the gendered and racialized relations of power in sport for development and football 
campaigns aimed at women's ${ }^{1}$ empowerment. Drawing from literatures across leisure, media and digital culture, sport, physical activity, health, science and technology studies, we position the performativity of gender as a central concern for thinking through the entanglement of physical and digital cultures, the flows and techniques of power as well as resistant formations of identity and difference. In this introduction we also map out issues and areas that are also missing in the collection as we consider future directions for feminist research in the post-disciplinary era. In our initial call for contributions we posed the following questions, which in turn shape the lines of inquiry across the collection;

- how are our cultural experiences of physicality 'gendered' in the context of changing leisure practices, social formations and relations of power?

- how do physical cultures work as performative sites that reiterate, and contest, normative notions of gendered personhood for women, transgender, gender fluid and masculine subjects?

- how are gender relations refused and transformed through everyday experiences, feminist knowledges, re-presentations and ontologies of gendered embodiment?

- how does a feminist Physical Cultural Studies sensibility inform the theoretical articulations of 'leisure'?

- how are gender relations embodied and assembled through digital leisure cultures?

- how can feminist physical cultural studies contribute to broader agendas about equity and inclusion in sport and leisure?

- how does engagement in feminist physical cultural studies foster critical public pedagogy, community engagement and activist endeavours?

The disruptive possibilities of feminist interventions into physical cultures opens up the politics of multiplicity that refutes dualistic thinking (masculine/feminine, mind/body, reason/emotion, culture/nature, work/leisure, pedagogue/learner etc), embraces becoming rather than boundedness, and advocates creative articulations rather than essentializing re-presentations of gender difference. We draw inspiration from the activism of Durham, Cooper and Morris (2013, p. 724), and the Crunk Feminist Collective, who advocate for a "percussive feminism" where the tensions between political and cultural projects like hip-hop and black feminism are both descriptive and generative. They suggest that, "Percussive feminism allows for the creativity that ensues from placing modes or objects of inquiry together that might not traditionally fit, hiphop and feminism being only the most obvious example" (2013, p. 724). These percussive possibilities for physical culture have prompted us to frame this collection in terms of the objects and forces that shape gendered embodiment and movement practices (and knowledge about such phenomenon) that entangle class, sexuality, ethnicity/race,

\footnotetext{
${ }^{1}$ We use the term women to refer to a gender category that is a matter of self-identification and subject positioning (cis and transgender). We also note the limitations of either or categories of gender for non-binary identifications.
} 
disability, age, culture, religion with particular spaces, institutional contexts and forms of embodied learning.

In this sense we seek to move away from notions of 'the body' in physical culture as a static object of knowledge production to encourage relational understanding, as Butler $(2014$, p.8) posits, "the body is less an entity than a relation, and it cannot be fully dissociated from the infrastructural and environmental conditions of its living". This feminist style of thinking leads us to ask, how can we continue to mobilise a visceral feminist politics of imagination (Pitts-Taylor, 2015; Latimer \& Skeggs, 2011) to unsettle, reveal and create ways to think otherwise about gender responsive practices, policies, pedagogies, organisations and forms of knowledge? With the changing global political landscape and ever present threats to gender equity from conservative governments, social justice and diversity (such as, the Trump administration's withdrawal of funding to global organisations that support abortion, the devaluing of women's testimonies about male violence in the Kavanaugh case, the rise of misogynist political leaders in Brazil and the perpetuation of austerity policies in the UK that significantly impact women's lives, and so on). There is an even more pressing need for creative feminist approaches that theorise, research and live out the 'personal as political' in different ways (Johnson \& Parry, 2016; van Ingen, 2016).

\section{Feminisms and Physical Cultural Studies}

The emerging post-disciplinary area of 'Physical Cultural Studies' (PCS) has sought to open up critical and hopeful dialogue about the social, political, economic, historical, geographic and cultural contexts of embodied movement (with collections such as the PCS special issue of Sociology of Sport Journal, 2011, The Routledge Handbook of Physical Cultural Studies, 2017, the special issue on Gender in Physical Culture: Crossing Boundaries - Reconstituting Cultures, Sport in Society, 2016, along with international conference activities and research group affiliations). Silk, Andrews and Thorpe (2017) put forward their case for the distinctiveness of PCS as "a dynamic and self-reflexive transdisciplinary intellectual project, rooted in qualitative and critical forms of inquiry...of the diverse realm of physical culture" (p. 5). The emergence of PCS ostensibly as an alternative framing to the more contained focus of sport sociology has elicited a range of responses that have begun to shape the direction of intellectual inquiry into how embodied movement is implicated in multiple power relations in ways that constrain and contest normalising imperatives (to look, act and become certain types of subjects). Within these debates feminists have called for critical approaches that engage more deeply with gendered forms of embodied movement and the onto-epistemological basis of theorymethodology to contest implicit assumptions about how bodies within PCS can default to an unacknowledged reliance on young, white, Western, masculine, middle class, heterosexual, ableness 
(Rich \& Sandlin, 2017; Adams et al, 2016; Pringle \& Falcous, 2016; Francombe-Webb \& Silk, 2015; Markula, 2015; Vertinsky, 2015; Pavlidis \& Olive, 2014; Pavlidis \& Fullagar, 2014; Thorpe, 2014; Thorpe, Barbour \& Bruce, 2011; Friedman \& van Ingen, 2011). Feminist critiques of PCS have often centred on the politics of knowledge production - the unacknowledged debt to feminist theories of culture (Adams et al, 2016) and embodiment (Fullagar, 2017b), as well as relational notions of power and feminist praxis (Olive, 2017). Such questions about the feminist politics of knowledge are not merely questions about 'theoretical slippages', rather they also point towards academic labour practices (the citation practices of men citing other men) that marginalise women's (and in particular women of colour) contribution to thought (and often career prospects)(Ahmed, 2017; Ratna, 2018).

Some feminists have remained outside the disciplinary boundaries of a PCS identity and instead have focussed on exploring the shifting gendered boundaries of physical cultures (Barker-Ruchti et al., 2016). Others have engaged with PCS sensibilities in different ways to open up the generative possibilities that different 'styles of thought' can offer in moving the analysis of physical culture towards more gendered understandings. Nikolas Rose (2009, p. 12) suggests that a style of thought is "a particular way of thinking, seeing, and practicing" that enables objects and processes to become intelligible in terms of the assemblage of knowledge produced. Thought styles are also produced collectively and inform shared understandings as members develop "a way of identifying difficulties, questioning arguments, identifying explanatory failures," but also as defining "what there is to explain" (Rose, 2009, p. 12). PCS has been articulated through certain styles of thought oriented around critical traditions of British and American Cultural Studies that understand power relations to be working through embodied, structural and cultural formations of neoliberalism. Gender has often been subsumed within these explanatory concepts. Yet, Toffoletti et al., (2018, p. 7) suggest multiple ways of bringing feminist critique into relation with the neoliberal conditions that produce gendered physical cultures as they "advocate for the development of new critical vocabularies through which to understand the effects and affects of gendered forms of power operating in sport and physical culture, as well as the new framing of old modalities of sexism and inequality, in a period characterised by neoliberalism and postfeminism".

In their paper for this issue, Holly Thorpe and Amy Marfell explore the tensions and possibilities of feminist PCS as an assemblage of knowledge practices that enables researchers to 'play' with different theories in ways that 'fit with' the empirical contexts that produce embodied experience. They also demonstrate how attention to the ethical issue of reflexivity and positioning in and through the research can generate feminist insights that emanate from embodied engagement with the contextual forces shaping netball in their case. In particular, Thorpe and Marfell draw our attention to those spaces where particular voices have been selectively erased and the inherent politics of doing feminist 
work in physical cultures. This selective erasure is no more apparent than in the lack of intersectional and Indigenous perspectives in the field of sport and leisure (Ratna, 2018; Henderson \& Gibson, 2013; Watson \& Scraton, 2013). The critique of whiteness and the need for intersectional and de/postcolonial understandings of gendered power relations is common concern that runs through several papers in the issue. Thorpe and Marfell bring into view post-colonial understandings through their engagement with Maori ontologies and methodologies in Aotearoa (New Zealand). In this way they work to open up FPCS and demonstrate a way to work with complexity across cultures.

Julie Brice and David Andrews also offer an analysis of how whiteness pervades American sport marketing (She Believes) in women's football where empowerment is mobilised as emancipation for all. Through a purposeful emphasis on whiteness, Brice and Andrews demonstrate the ways race is erased in women's sport (in this case soccer) through an emphasis on individual effort, 'empowerment', 'success' and 'girl power'. In a very different context, Sarah Oxford and Ramon Spaaj develop a feminist decolonial approach to researching sport development with women in Colombia. Feminist decolonial theories importantly open up questions about the diversity of 'women's' bodies by pursuing accounts of how gendered power is enacted through colonised histories and capitalist imaginaries in the present (Ratna, 2018). As Lugones (2010, p. 742) argues "the colonial imposition of gender cuts across questions of ecology, economics, government, relations with the spirit world, and knowledge, as well as across everyday practices that either habituate us to take care of the world or to destroy it". Physical cultural practices are entangled with colonial histories and ways of knowing-valuing gendered embodiment that are highly normative and racialised in the production of whiteness in a privileged relation to black and brown bodies.

The recent example of the Serena Williams being harshly sanctioned at the 2018 US Open for speaking back to the umpire has been the subject of public debate over sexist and racist double standards in tennis given that white, male players rarely receive the same judgement. Black women risk far greater backlash when questioning sport standards, which is something that bell hooks and Melissa Harris-Perry (2013) discuss in their dialogue about the conditions of possibility that shape how Black women's voices can be heard in America. They raise the conundrum of how Black women are positioned when they speak back and challenge multiple forms of oppression that remain hidden beneath universalised truths (white, imperial, capitalist, patriarchial...). Harris-Perry may have a mediated platform through her own television show yet speaking back continually invokes stereotyped characterisations that shift the focus from politicised issues to a personalisation of 'those angry and difficult Black women'. Writing in an English context, Ahmed (2014) also refers to this dynamic as a 'politics of dismissal' in terms of how dissenting voices are swept away with the charge of 'wilfulness'. She argues that being positioned as a 'wilful subject' is also part of a broader 
characterisation of women as 'feminist killjoys'. To speak against powerful interests or to reveal the normative assumptions that have historically excluded certain raced, classed and gendered (nonheterosexual and able) bodies is to risk the appropriation of feminism in various media where questions of injustice are turned into internal, emotional states of subjective being (anger, unhappiness).

\section{Physical Cultures and Feminist Post-humanism}

Posthumanist, postcolonial and new materialist trajectories may well lead feminists to refuse, reconfigure or abandon the bounded metaphor of 'the PCS field' as a means of thinking more relationally, beyond boundary making. Such thinking emphasises the styles, entanglements and lines of flight that connect physical cultures with particular kinds of gendered problematisations that are entangled with embodied health, violence, erasure of otherness, more-than-human worlds, pedagogic practices and digital transformations. Bradiotti (2013) has written of this challenge in terms of thinking through the complexities of post-humanism where personhood is understood beyond the universalised gaze of an imperial, masculine subject as well as historically limited culture-nature, nature-technology oppositions. A feminist posthumanism treads the fine line of decentering the intentional, voluntaristic subject and pursuing the material, affective and discursive forces that are implicated producing a vital politics of life itself (Bradiotti, 2013). These include the shaping of minds and bodies by neurobiology, technologically mediated practices and diverse media spaces, new forms of gender identification, to shifting relations with non-human animals/ environments and changing notions of health, wellness and the provision of public services in advanced liberalism.

The discourse around health inequalities provides a common starting point from which to explore differences in the very way in which we imagine, live and conceptualise embodiment. Longitudinal studies of social context reveal how bodies are marked by the effects of intergenerational inequality, while biologists studying gut health argue that we are already post-human with bacterial cells out numbering human cells ten to one and neurobiology, pharmaceutical products are altering the way in which we understand what are 'normal' emotions and health technologies are enthusiastically taken up in self tracking practices despite issues of privacy and surveillance. In framing her published interview with feminist biologist Lynda Birke, Asberg and Birke (2010) writes,

As we enter an age in which biology no longer easily associates with the given, but rather with the modifiable and with technoscientific change, there is urgent need to reopen the feminist debates and rethink biology in more productive ways than those limited by disciplinary divisions of either human and social sciences (focusing on culture and society) or natural sciences (focusing on nature) (p. 414). 
This is true for biology, as for the other 'sciences', once relegated to the margins of social science research. Feminist knowledges have and continue to intervene in physical cultures in surprising and important ways, connecting with PCS in the desire of its proponents to open up the study of physical cultures beyond 'sport'. In this way PCS refuses the "all-too-easy adoption of empirical, theoretical, and/or methodological certainties" (Silk, Andrews \&Thorpe, 2017, p. 2) advanced in other fields of study, while also signposting the influential works of numerous feminist scholars. Feminist scholars have been at the forefront of intellectual thought about embodiment (for example, Haraway, 2013; Braidotti, 2011; Bordo, 2004; Butler, 2002; Grosz, 1994; Irigaray, 1985) and these contributions have at times been under acknowledged. This special issue brings feminist knowledge to the fore in its ongoing critique and articulation of what PCS is, and, perhaps more importantly, what PCS or studies of physical culture can do.

In thinking about what feminist interventions in physical culture can do, health is of particular importance for feminist scholars because of the effects of inequality and the gendered history of medical intervention on women's lives. Given the growing connections in policy and research between physical culture and health, social science research can draw insights from adjacent fields of study, such as critical medical humanities (Viney et al., 2015) and feminist science and technology studies (Wyer, et al., 2013), where similar debates are being had about diverse ways of knowing the object of analysis in the post-disciplinary era. Old divisions are being challenged as scholars articulate the productive and ongoing connections between organised sport, everyday practices, and health. Part of this challenge is an acknowledgement of the non-human, together with human agency, as implicated in particular assemblages. Indeed, writing of assemblages is one way of articulating the sense of structure and fluidity (Marcus \& Saka, 2006) and the human and non-human relations that come to affect particular physical cultures.

In a posthumanist move beyond the limitations of social constructionist thinking about the 'context' of embodied movement, Evers and Germon (2017, p. 143) ask, "how can physical cultural studies account for the dynamic complexity of the inter- and intra-action of biology, environment, society with experience?". Fullagar (2017b) also argues for engagement with a different set of ontoepistemological assumptions that reorient "thinking around relational questions about the materialdiscursive forces that are co-implicated in what bodies can 'do' and how matter 'acts'. This focus differs from more conventional approaches concerned with what 'is' a body or the agentic meaning of experience that have characterized humanist interpretivist traditions (St. Pierre 2014, 2015)” (p. 249). Shannon Jette, Katelyn Esmonde and Julie Maier's paper pursues this line of thinking to develop a transdisciplinary perspective on prenatal physical activity guidance in relation to the "postgenomic turn'. In their article they align feminist new materialist approaches with the social justice agenda of 
PCS to demonstrate how scientific studies on physical activity in pregnancy -- with the goal of reducing the fetuses risk of future obesity -- are solely focused on the agency of a unified and rational human actor. That is, the mother. The non-human, including social structures, neighbourhoods, taxes, price of entry, and so on, are completely ignored, and issues of trauma and intergenerational poverty sidelined as an issue for further education. Hence, while Jette, Esmonde and Maier view physical activity in pregnancy as valuable, they are working through issues of power and politics inherent within the 'postgenomic turn'. This is a challenging task, as they discuss in their article, however feminisms and PCS provide an important space for the articulation of these complex but vital ideas.

The emergence of post-qualitative inquiry and feminist new materialist theories has opened up different concerns about the politics of knowledge, ethics and re-presentation of 'data' in leisure studies and PCS (Fullagar, Pavlidis \& Francombe-Webb, 2018; Fullagar, Parry \& Johnson, in press). Post-qualitative research opens up what 'counts' as data and questions the ontological assumptions that shape how research 'represents' the world and embodied experiences. While some PCS scholarship has importantly engaged with creative ways of writing research and forms of bricolage, it has only been recently that questions of onto-epistemology have begun to inform a broader 'deterritorialization' (Braidotti, 2011; Deleuze \& Guattari, 1987) of theory-method approaches to physical culture. As new materialists remind us, a "body... does not exist - a body is not, it does", bodies exists through a process of encounters and intra-actions (Manning, 2009 in Hickey-Moody \& Page, 2016, p. 5). The corollary of this is a reappraisal of what it means to 'do' research. As HickeyMoody (2016) outlines in her manifesto on the rhizomatics of practice as research, there are "distinctions between what it means to 'do' research and to 'make' through contemporary practices or arts-based processes" (p. 171). Similarly, van Ingen (2016) engaged in a generative approach using paintings created by female and trans boxers in a trauma and violence informed, non-contact boxing program to explore the ways 'making' produced new thinking in response to gendered violence, as well as within sport for development and peace initiatives. Increasingly value is being placed on research inquiry that is more ontologically focused, postcolonially aware, embodied, affective, and that holds relational understandings of research processes.

John Ray's article, 'Becoming footballer: an autoethnographic inquiry' makes an important contribution in acknowledging the ways feminist methodological innovations can intervene into ways of knowing and 'being' a man in sport and physical cultures. In his article he argues for the importance of problematising dominant enactments of masculinity through feminist theories and in doing so supports an understanding of feminism as not simply a 'woman's problem', but more broadly about gender relations, and masculinities. In particular, Ray reflects on previous uses of affect theory and autoethnography in sport contexts (for example, Pavlidis, 2012, 2013) and how these ways of 
conceptualising the 'self' in relation to others (the human and non-human) in research can intervene into spaces and practices deemed as 'masculine' physical cultures (such as Australian rules football, which is the context of his study). Drawing upon similar theoretical concerns with understanding the gendered forces of affect, Julia Coffey's article explores feminist limits and possibilities surrounding the enactment of gendered 'body work' in the context of how women create 'distance' from troubling embodied relations that are produced through the value accorded to perfection and thinness. Drawing upon feminist new materialist thinking, Coffey argues for an assemblage model to theorise gender 'as a functional, active arrangement of connections which operates as only a temporary articulation or territorialisation rather than an essential identity category'. She also offers a critical-creative approach to writing through affect that foregrounds the 'fragments' and contradictions in women's stories, rather than privilege narrative coherence. In doing so, her article explores the 'potential for feminism to open possibilities to imagine the body otherwise' in the pursuit of social justice that recognises the partiality of all knowledge interventions.

\section{Feminist Engagement with Digital and Physical Cultures}

Feminist scholars and activists have been interested in the relationship between technology and gender, both in terms of constituting gender (Wajcman, 2004, 2007) and also as a means through which to resist normalising gender discourses. More recently, with an expanding range of digital devices, our gendered, moving bodies and subjectivities have become increasingly digitised as part of our engagement with physical cultures. Such technologies are diverse and they can play a significant role in the way in which physical cultures are assembled. In terms of leisure, these include, but are not limited to social media, mobile apps, wearable devices which track our movement and bodily behaviours, through to more recent 'ingestible' sensor technology. Of growing popularity in health and fitness, are those technologies which Gilmore describes as 'everywhere' and which are "tethered to bodies and, through habitualization, designed to add value to everyday life in the form of physical wellbeing” (Gilmore, 2015, p.2). As such, digitised 'leisure' practices (Lupton, 2016; Silk, Millington, Rich \& Bush, 2016) has caught the attention of Leisure Studies, however, feminist analysis is only beginning to emerge (Fullagar, Parry \& Johnson, in press; Rich, in press) .

Robinson et al (2015, p. 569-570) argue that "digital inequality deserves a place alongside more traditional forms of inequality in the twenty-first century pantheon of inequalities" claiming that "it has the potential to shape life chances in multiple ways". In other words, datafication, whilst often focused on data about the individual, has broader social impacts, including upon the way in which these practices are shaped by broader sociocultural contexts and gendered power relations. There remain challenges which confront us in terms of how we might undertake research on aspects of 
digitised leisure, not least in terms of the various elements of how we are "living with and by our data" as gendered subjects (Lupton, 2016, p.709). These digital technologies are continuing to develop at a rapid pace and as such this may require us to be creative and open to the way we do theory-methods. As Beck terms it, "Live sociology" requires researchers to work on the move in order to attend to the “newly coordinated' nature of social reality" (Back, 2012, p. 29). This means considering how as researchers we think about the complexity and nuanced practices and relationalities between gendered bodies and technology. The complexity of digital social relations presents challenges, opportunities and potential inequalities. Historically, digital technologies have been constituted through polarised debates which position them through techno-dystopic or techno-utopic discourses. Rather than positioning digital technologies as either inherently liberating or oppressive, the work in this collection points towards the complex affective relationalities between data, user and the the gendered body (Rich, 2018). Informed by the relational approaches described above we can understand these practices as entangled and as such integral to the process of emerging meanings and practices that produce 'the body'.

Taking up this approach, Barry and Waitt's article examines the gendered dynamics of Strava, a popular cycling platform which is an example of the now vast number of digital technologies designed to track and monitor physical activity. They offer the concept of the cycling assemblage to explore these gendered subjectivities 'on-the-move', recognising this process of becoming as an ongoing negotiated relationship between cycling, bodies and technologies. Like other health and fitness technologies, Strava not only tracks the body (e.g. heart rate, distance, times etc) but has the capacity for performances to be shared with other uses as part of a social network. Whilst digital technologies such as these are often promoted on the basis of empowerment, Barry and Waitt draw attention to the way in which Strava is part of a cycling assemblage in ways which function as 'a mechanism of gendered inclusion and exclusion'. Barry and Waitt present vignettes to illustrate how cycling assemblages generate excess and tension, often in multiple ways, promoting pleasure and pride, but also confusion, anger, pain and shame. In exploring these complexities, their paper points towards the need to understand the relationships between 'gender, physical culture and mobility in leisure activities'.

The growth of consumer-oriented technologies like Strava, which are pertinent to promoting healthy lifestyle behaviours, such as physical activity, body weight management, and food consumption raise questions about how gendered bodies are assembled, particularly within postfeminist and neoliberal contexts. Dobson (2015, p.159) in her work on postfeminist digital cultures has 'problematized the kind of idealised and popular femininity which structures and frames young women's engagement with digital media'. Dobson reminds us of the way in which self-representations in digital 
environments 'complicate the binary of object/subjecthood' (p.160). Similarly, Brice and Andrews in this special issue draw attention to the complicated and sometimes contradictory ways in which women experience discourses of neoliberal empowerment. Concerns continue to be raised about expectations to track our bodies or to digitally represent ourselves as part of postfeminist and neoliberal imperative, positioning digital technologies as a route to 'self betterment' or 'selfoptimization' (Ruckenstein, 2014, p.69). Gender subjectivity is constantly negotiated through digital assemblages and emerges through a complex discursive and material entanglement in often unpredictable ways. As physical cultures become more and more digitised, future feminist work will need to engage with the relational questions (Fullagar, 2017) described above. For example, the recent emergence of ingestible sensors (or ingestibles) is perhaps suggestive of a future which is advancing from wearable to ingestible technology; such trajectories will require a deeper understanding of those entanglements in terms of the interplay between biology, technology and the body. At the time of writing this article, it was announced that researchers had developed a 'proof-of-concept' flexible sensor that can be folded up into a pill and ingested with the potential for transmitting data about the stomach and when a person is eating or drinking. Such technologies might provide important data for the management of particular health conditions, but one might question whether such products could also be developed into futurelifestyle enhancements that target women's bodies and appetites . Such technically mediated practices raise will raise questions not only about the gendered body and what such mediated bodies can do or become, but so too it will raise numerous bioethical questions as we move towards more automated and invasive forms of digital technologies.

\section{Silences, Frictions and Feminist Futures}

This special edition on feminist knowledges as interventions in physical cultural studies is by no means exhaustive (for related work see, Mansfield, Caudwell, Wheaton \& Watson, 2018). What we have aimed to do is create space for the articulation of a range of theoretically and methodologically diverse approaches to physical culture in the pursuit of a "percussive feminism" (Durham, Cooper \& Morris, 2013, p. 724). In this sense, the percussive possibilities of thinking arise from the relations 'between' each contribution as shared social justice concerns refract through both frictions and synergies. Some contributors have pursued an articulation of a distinct Feminist Physical Cultural Studies ethos, for others it is has been a matter of reconfiguring the disciplinary boundaries of knowledge and the gendered politics of physical cultures. However, there are many gendered forms of embodiment - human and non-human - missing that are important to name. For example, while dualisms of male-female, biology-culture have historically underpinned sporting rules they are coming under increasing public scrutiny given the discriminatory treatment of intersex, queer, trans and nonbinary athletes. While we were unable to include contributions that examined these significant issues, 
we point readers towards the growing feminist literature in this area and potential for future research into queer knowledges and gender diverse bodies (Davidson 2018; Travers 2018).

In addition, there is a growing body of (eco)feminist post-humanist work that has begun to explore more-than-human leisure relations with nature, 'the environment'and non human animals (Bertella 2018; Finkel \& Danby 2018; Dashper, 2016). This work questions the assumed mastery of nature and hierarchical separation of human bodies from the fleshy and non-organic composition of our shared life worlds. In this sense, physical cultures produce embodied movement that is not simply 'through' the world but rather is composed 'of' naturecultures that are imbricated in the spacetime mattering of becoming (Barad, 2007). However, the materiality of becoming and the performativity of gendered embodiment is never simply free from discourse and the digital mediations of contemporary culture.

In a very practical sense these conceptualisations of the material-discursive dimensions of physical culture play out through the intersections between climate change, gender inequality and global capitalism where women and children of colour are positioned as the most vulnerable to social, economic and political processes. Feminist decolonial, Indigenous and posthumanist thinking importantly highlights the distinct ways of knowing that have been historically marginalised and excluded by white, western, masculine cultural imagining (Ratna, 2018). Collectivist, non-competitive ways of relating to the more than human world challenge privilege and open up important ways of doing, moving and thinking through different ontologies of world making. There is much work to be done in pursuing questions of entangled understandings of gendered embodiment, decolonial practices and postcolonial reverberations as they shape feminist interventions in knowledge. This may involve different kinds of activism, from strategic essentialism (Spivak, 2013) that deploys 'woman' as an identity (along with race, sexuality, disability etc) to challenge the invisibility (of how) gender differences (get made). Other strategies have also been adopted by feminists to queer and diffract the ontologies that underpin our relationality as a means of reimagining the gendered contours of naturecultures and physicaldigital worlds (Barad, 2007).

We hope this collection contributes to the ongoing movement of debate within and across PCS in order to entangle physical cultures with a range of gendered problematisations and interventions that require different ways of knowing, imagining and doing feminisms. This aspiration connects us with the growing work within the field public pedagogy, which in broad terms examines the "spaces, sites and languages of learning" that occur outside of or beyond formal educational institutions (Sandlin, Schultz and Burdick, 2010, p.1) Certainly the work in this collection speaks to the educative force of a range of different physical cultures and sites. Framed through this lens of public pedagogy, the contributions in this issue have articulated how different physical cultures operate pedagogically - that 
is to say, teaching us certain ways of thinking about gendered bodies, health and movement. At the same time, postfeminist discourses continue to circulate in popular leisure and physical cultures (Fullagar, Pavlidis \& Francombe-Webb, 2018). There remains much work to be done in terms of not only understanding these pedagogical enactments, but so too in terms of identifying new ways of knowing and intervening. As Hickey-Moody et al., (2010, p. 229) suggest that, "a sophisticated notion of pedagogy does not assume a simple movement of norms from society to individual. Instead, norms can be examined as they are developed and contested". Examples of contestation within the physical cultures described in this collection and beyond raise questions about the shifting relations of gendered power, inequality and privilege.

These concerns also trouble our positioning as scholars, for example in terms of what it means to undertaken public engagement, activist and 'impact' work in order to intervene, collaborate and make a difference (See Rich \& Sandlin, 2016). Recent work in the field of public pedagogy has questioned both the individualistic model of the 'public intellectual' towards more feminist and communal visions of public intellectualism (Dentith, O’Malley \& Brady, 2014). The opportunities for citizen journalism, politics and activism through emerging digital platforms are perhaps examples of these forms of communal engagement; consider for example the power of hashtag activism. In her recent paper Ringrose (2018, p. 654) explores how we can use "digital platforms like Twitter to investigate power, privilege and positionality" but also highlights the risks whereby "feminist pedagogues are confronted with the denial and attack of our intersectional feminist analyses in the 'post-truth' Trump era". With the rapid development of new digital ecologies and media platforms further work is needed to examine the possibilities for feminist pedagogies of physical culture within and through these spaces and the capacity "for citizens to engage as critical educators in their present everyday lives" (Brady, 2006, p. 58). Finally, in enacting feminist physical cultures this may require engaging with different communities, publics and sites through relationality, affectivity and embodiment (see Burdick et al., 2014). In this regard, arts based feminisms or arts-based feminist public pedagogies encourage us to "develop forms of visual culture that provide new/alternative ways of imagining the physically active body" (Rich \& Sandlin, 2016, p. 555). Forms of 'creative engagement' (Brady, 2006) with film, video, dance, performance art, marketing, television, digital platforms, new media, social media provide opportunities for provocations which trouble the normalcy of gendered differences. 


\section{References}

Adams, M. L., Davidson, J., Helstein, M. T., Jamieson, K. M., Kim, K. Y., King, S., \& Rail, G. (2016). Feminist cultural studies: Uncertainties and possibilities. Sociology of Sport Journal, 33(1), 75-91.

Ahmed, S. (2017). Living a feminist life. Durham: Duke University Press.

Ahmed, S. (2014). Willful subjects. Durham: Duke University Press.

Åsberg, C., \& Birke, L. (2010). Biology is a feminist issue: Interview with Lynda Birke. European Journal of Women's Studies, 17(4), 413-423.

Back, L (2012) Live sociology: Social research and its futures. The Sociological Review 60, 18-39.

Barad, K. (2007). Meeting the universe half-way: Quantum physics and the entanglement of matter and meaning. London: Duke University Press

Barker-Ruchti, N., Grahn, K., \& Lindgren, E. C. (2016). Shifting, crossing and transforming gender boundaries in physical cultures. Sport in Society, 19(5), 615-625.

Bertella, G. (2018). An eco-feminist perspective on the co-existence of different views of seals in leisure activities. Annals of Leisure Research, 21(3), 284-301.

Bordo, S. (2004). Unbearable weight: Feminism, western culture, and the body. Oakland, CA: University of California Press.

Butler, J. (2002). Gender trouble. New York: Routledge.

Butler, J. (2014). Rethinking vulnerability and resistance. Lecture, Madrid.

Braidotti, R. (2013). The posthuman. London: John Wiley \& Sons.

Brady, J.F. (2006). Public Pedagogy and Educational Leadership: Politically engaged scholarly communities and possibilities for critical engagement. Journal of Curriculum and Pedagogy, 3(1), 57-60

Braidotti, R. (2011). Nomadic subjects, New York: Columbia University Press.

Dashper, K. (2016). Human-animal relationships in equestrian sport and leisure. London: Routledge.

Davidson, J. (2018). Queering leisure: teasing out queer theory's legacies. In D. Parry (Ed.), Feminisms in leisure studies: Advancing a fourth wave. (pp. 93-115). London: Routledge. 
Deleuze, G., \& Guattari, F. (1988). A thousand plateaus: Capitalism and schizophrenia. London: Bloomsbury Publishing.

Dobson, A. R. S. (2015). Postfeminist digital cultures: Femininity, social media, and self-representation. New York: Palgrave Macmillan.

Durham, A., Cooper, B., \& Morris, S. (2013). The stage hip-hop feminism built: A new directions essay. Signs, 38(3), 721-737.

Evers, C \& Germon, J. (2017). Gendered bodies. In M. Silk, D. Andrews and H. Thorpe (Eds.), Routledge handbook of physical cultural studies. (pp. 141-149). London: Routledge.

Finkel, R., \& Danby, P. (in press 2018). Legitimizing leisure experiences as emotional work: A post-humanist approach to gendered equine encounters. Gender, Work \& Organization. https://doi.org/10.1111/gwao.12268.

Francombe-Webb, J., \& Silk, M. (2015). Young girls' embodied experiences of femininity and social class. Sociology. 50(4), 652-672.

Friedman, M. T., \& van Ingen, C. (2011). Bodies in space: Spatializing physical cultural studies. Sociology of Sport Journal, 28(1), 85-105.

Fullagar, S., Parry, D. \& Johnson, C. (in press). Digital dilemmas through networked assemblages: Reshaping the gendered contours of our future. In D. Parry, C. Johnson \& S. Fullagar. (Eds.), Digital dilemmas: Transforming gender identities and power relations in everyday life. (p. 225-244). London: Palgrave Macmillan.

Fullagar, S., \& Pavlidis, A. (2018). Feminist theories of emotion and affect in sport. In L. Mansfield., J. Caudwell, B. Wheaton, \& B. Watson. (Eds.), The palgrave handbook of feminism and sport, leisure and physical education. (pp. 447-462). London: Palgrave.

Fullagar, S., Pavlidis, A \& Francombe-Webb, J. (2018). Feminist theories after the poststructuralist turn. In D. Parry (Ed.), Feminisms in leisure studies: Advancing a fourth wave. (pp. 48-71). London: Routledge.

Fullagar, S. (2017a). Post-qualitative inquiry and the new materialist turn: implications for sport, health and physical culture research. Qualitative Research in Sport, Exercise and Health, 9(2), 247-257.

Fullagar, S. (2017b). Mind-body relations in physical cultural studies. In M. Silk, D. Andrews \& H. Thorpe. (Eds.), Routledge handbook of physical cultural studies (pp. 401-411). London: Routledge.

Gilmore, J.N. (2015). Everywear: The quantified self and wearable fitness technologies. New Media and Society, 1-16. Doi: 10.1177/1461444815588768 
Grosz, E. A. (1994). Volatile bodies: Toward a corporeal feminism. Indiana University Press.

Haraway, D. (2013). Simians, cyborgs, and women: The reinvention of nature. Routledge.

Henderson, K. A., \& Gibson, H. J. (2013). An integrative review of women, gender, and leisure: Increasing complexities. Journal of Leisure Research, 45(2), 115135.

Hickey-Moody, A. \& Page, T. (2016). Introduction: Making Matter Matter. In HickeyMoody, A. \& Page, T. (Eds.), Arts, Pedagogy and Cultural Resistance: New Materialisms. (pp. 1-20). Rowman \& Littlefield: New York.

Hickey-Moody, A. (2016). Manifesto: The Rhizomatics of Practice as Research. In Hickey-Moody, A. \& Page, T. (Eds.), Arts, Pedagogy and Cultural Resistance: New Materialisms. (pp. 169-192). Rowman \& Littlefield: New York.

hooks, b. \& Harris-Perry, M. (2013). Black feminist voices: Who is listening, The New School. $8^{\text {th }}$ November, http://livestream.com/TheNewSchool/blackfemalevoices/videos/34324981, accessed 18/09/2017.

Irigaray, L. (1985). This sex which is not one. Ithaca: Cornell University Press.

Johnson, C. W., \& Parry, D. C. (Eds.). (2016). Fostering social justice through qualitative inquiry: A methodological guide. Routledge: New York.

Latimer, J., \& Skeggs, B. (2011). The politics of imagination: keeping open and critical. The Sociological Review, 59(3), 393-410.

Lugones, M. (2010). Toward a decolonial feminism. Hypatia, 25(4), 742-759.

Lupton, D. (2016). The quantified self. London: John Wiley \& Sons.

Mansfield, L., Caudwell, J., Wheaton, B., \& Watson, B. (Eds.), The palgrave handbook of feminism and sport, leisure and physical education. Palgrave Macmillan, London.

Marcus, G. E., \& Saka, E. (2006). Assemblage. Theory, culture \& society, 23(2-3), 101-106.

Markula, P. (2015). Assessing the sociology of sport: On sport and exercise. International Review for the Sociology of Sport, 50(4-5), 536-541.

Olive, R. (2017). The political imperative of feminism. In M. Silk, D. Andrews and H. Thorpe (Eds.), Routledge handbook of physical cultural studies. (pp.51-61). London: Routledge.

Pavlidis, A. (2012). From riot grrrls to roller derby? Exploring the relations between gender, music and sport. Leisure Studies, 31(2), 165-176. 
Pavlidis, A. (2013). Writing resistance in roller derby: Making the case for auto/ethnographic writing in feminist leisure research. Journal of Leisure Research, 45(5), 661-676.

Pavlidis, A. \& Fullagar, S. (2014). Sport, gender and power: the rise of roller derby. Ashgate: London.

Pavlidis, A., \& Olive, R. (2014). On the track/in the bleachers: authenticity and feminist ethnographic research in sport and physical cultural studies. Sport in Society, 17(2), 218-232.

Pitts-Taylor, V. (2015). A feminist carnal sociology?: Embodiment in sociology, feminism, and naturalized philosophy. Qualitative Sociology, 38(1), 19-25.

Pringle, R., \& Falcous, M. (2016). Transformative research and epistemological hierarchies: Ruminating on how the sociology of the sport field could make more of a difference. International Review for the Sociology of Sport. 53(3), $261-277$

Ratna, A. (2018). Not just merely different: Travelling theories, post-feminism and the racialized politics of women of color. Sociology of Sport Journal, 35(3). 197206.

Rich, E. (in press). Making gender and motherhood through pedagogies of digital health and fitness consumption 'soon it made us more active as a family'. In D. Parry, C. Johnson and S. Fullagar (Eds.), Digital dilemmas: transforming gender identities and power relations in everyday life. London: Palgrave Macmillan

Rich, E. (2018). Gender, health and physical activity in the digital age: Between postfeminism and pedagogical possibilities, Sport, Education and Society, 23(8), 736-747.

Rich, E., \& Sandlin, J. (2017). Public pedagogies of physical cultural studies:

Problematizing pedagogy and public interventions in/as physical cultural studies. In M. Silk, D. Andrews and H. Thorpe (Eds.), Routledge handbook of physical cultural studies. (pp.549-557). London: Routledge

Ringrose, J. (2018). Digital feminist pedagogy and post-truth misogyny, Teaching in Higher Education, 23(5), 647-656.

Robinson, L., Cotten, S.R., Ono, H., Quan-Haase, A., Mesch, G., Chen, W., Schulz, J., Hale T.M. \& Stern, M.J. (2015). Digital inequalities and why they matter, Information, Communication \& Society, 18(5), 569-582.

Rose, N. (2009). The politics of life itself: Biomedicine, power, and subjectivity in the twenty-first century. Princeton: Princeton University Press. 
Ruckenstein, M. (2014). Visualized and interacted life: Personal analytics and engagements with data doubles. Societies, 4, 68-84.

Sandlin, J., Schultz, B., and Burdick, J. (2010). Handbook of public pedagogy: Education and learning beyond schooling. New York: Routledge

Silk, M, Millington, B, Rich, E \& Bush, A. (2016). (Re-)thinking digital leisure. Leisure Studies, 35(6), 712-723.

Silk, M, Andrews, D \& Thorpe, H. (2017). (Eds.), Routledge handbook of physical cultural studies. London: Routledge.

Spivak, G. (2013). The Spivak reader: Selected works of Gayati Chakravorty Spivak. London: Routledge.

Thorpe, H. (2014). Moving bodies beyond the social/biological divide: Toward theoretical and transdisciplinary adventures. Sport, Education and Society, 19(5), 666-686.

Thorpe, H, Barbour, K \& Bruce, T. (2011). "Wandering and wondering”: Theory and representation in feminist physical cultural studies. Sociology of Sport Journal, 28(1), 106-134.

Toffoletti, K., Francombe-Webb, J., \& Thorpe, H. (2018). New sporting femininities: Embodied politics in postfeminist times. Champagne: Palgrave Macmillan.

Travers, A. (2018). Transgender issues in sport and leisure. In L. Mansfield., J. Caudwell, B. Wheaton, \& B. Watson. (Eds.), The palgrave handbook of feminism and sport, leisure and physical education. (pp. 649-665). London: Palgrave Macmillan.

van Ingen, C. (2016). Getting lost as a way of knowing: the art of boxing within Shape Your Life. Qualitative Research in Sport, Exercise and Health, 8(5), 472-486.

Viney, W., Callard, F., \& Woods, A. (2015). Critical medical humanities: Embracing entanglement, taking risks. Medical Humanities, 41(1), 2-7.

Vertinsky, P. (2015). Reconsidering the female tradition in English physical education: The impact of transnational exchanges in modern dance. International Journal of the History of Sport, 32(4), 535-550.

Watson, B., \& Scraton, S. J. (2013). Leisure studies and intersectionality. Leisure Studies, 32(1), 35-47.

Wajcman, J. (2004). Technofeminism. Cambridge: Polity Press.

Wajcman, J. (2007). From women and technology to gendered technoscience. Information, Communication \& Society, 10(3), 287-298. 
Wyer, M., Barbercheck, M., Cookmeyer, D., Ozturk, H., \& Wayne, M. (2013). Women, science, and technology: A reader in feminist science studies. London:

Routledge. 